（33）アレー観測記録を用いた最大加速度の空間分布に関する研究

埼玉大学工学部 正会員 川上英二

埼玉大学工学部 学生員 $\bigcirc$ 西 一彦

埼玉大学工学部 正会員 茂木秀則

\title{
1. 研究の目的
}

1993年の釧路沖地震では、釧路気象台で0.7gを越える最大加速度を記録したのに対して、その近くの観測 点では数割小さい最大加速度が観測されている。被災した構造物の解析に際しては近くの地晨計による観測 結果を用いることが多く、観測値が場所の違いに関してどの程度安定しているのかを検討することは重要で あると考えられる。

本研究ではそのまず第一歩として、強震動のアレー観測記録を用いて地表の 2 観測点の最大加速度の比と 2 観測点間距離の関係を調べた。そして、震源距離の違いの影響が無視できるような非常に近い2 観測点間 で、最大加速度がどの程度安定しているかを調べた。本研究では、2 観測点間距離を数十から数百メートル という比較的近い点に限定し、東京大学生産技術研究所片山・山崎研究室による千葉アレーの記録と、電力 会社の共同プロジェクトによるいわきアレーの記録を用いて、同一のアレー内の 2 点の最大加速度比につい て檢討した。

なお、千葉アレーでは地下 $1 \mathrm{~m}$ に設置された15個の同一タイプの加速度計の記録を、いわきアレーでは地 表に $66 \mathrm{~m}$ 離れて設置された 2 個の同一タイプの加速度計の記録を使用した。千葉アレー観測点での地盤構造 は、場所による違いが顕著でなくほぼ一様である”。

\section{2. 地震による比の違い}

2 点間距離と水平最大加速度比の関係において地縟による違いが明らかな例をFig.1、Fig. 2に示す。これ らの図では、横軸に 2 点間距離、綐軸に最大加速度比をとっている。ここで言う水平最大加速度とは水平二 成分のベクトル和の最大值である。また、(最大加速度)比は 2 地点の最大加速度を大きい方で除して求めて おり、綎軸の值は常に 1 以下である。

Fig. 1は、1984年9月14日に観測されたマグニチュードM=6.8、震源深さ $D=2.0 \mathrm{~km}$ 、震央距離 $L=231 \mathrm{~km}$ 、千葉 アレーでの水平最大加速度 Amax $=5 \mathrm{gal}$ の地震に対する結果である。

本地㹉では次の特徵、

1） 2 点間距離が $0 \sim 40 \mathrm{~m}$ の場合、最大加速度の比は 0.9 付近に集中している。

2） 2 点間距離が100〜 160mの場合も、最大加速度の比は0.9付近に集中している。

3) 最大加速度比のばらつきが比較的小さい。

が挙げられ、近い 2 点の最大加速度がそれほど変化していない地震の例である。なお、図中には最小自乗法 を用いた回帰直線も示してあり、この直線の傾きが小さく、最大加速度比が 2 点間の距離によりそれほど違 わないことがわかる。

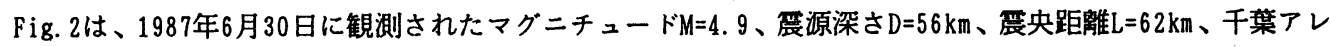
一での水平最大加速度 $46 \mathrm{gal}$ の地覆に対する結果である。本地䟴では、

1） 2 点間距離が0〜 $40 \mathrm{~m}$ の場合です、最大加速度比は $0.7 \sim 1$ に分布する。

2） 2 点間距離が100〜160mの場合、最大加速度比は $0.5 \sim 0.8$ に分布する。

3) Fig.1の地票と比較すると最大加速度比のばらつきが大きい。

の3つが特徵として挙げられる。本地震では回帰直線の傾きが大きく、2 点間の距離が百メートル程度の場 合でも最大加速度が平均して約 3 割、場合によっては 5 割程度異なることがわかる。 


\section{3. 観測点間距離と最大加速度の比の関係}

Fig. 3、Fig.4は、千葉アレーといわきアレーで観測された87個の地磦記録から求めた、2 点間距離-最大加 速度比の関係をFig.1、Fig. 2と同様にプロットしたすのである。図中、千葉アレーの記録を用いた結果を黒 い点でプロットし、いわきアレーの記録を用いた結果を白丸で示している。Fig. 3とFig.4を比較すると水平 動より上下動の方が 2 点間の最大加速度の違いが大きいように思われる。

次に、南北成分と東西成分のそれぞれに対し、2 観測点間距離と最大加速度比の関係を千葉アレーの記録 を用いて求めた結果を、Fig. 5、Fig. 6に示す。これらの図から、比較的離れた (150 m以上) 2 点では東西成分 の方がばらつきが大きい傾向を読みとることができる。

\section{4. 最大加速度の確率分布}

次に、千葉アレーの記録を用いて、2 点間距離をパラメータとして最大加速度比の確率分布について検討 した。Fig.7は水平最大加速度比、Fig. 8は上下最大加速度比、Fig. 9は南北方向の最大加速度比、Fig.10は東 西方向の最大加速度比をそれぞれ横軸にとり、最大加速度比の確率密度を縦軸に示したすのである。

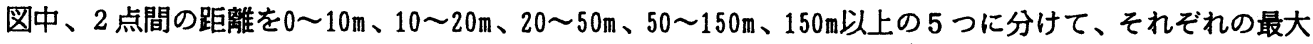
加速度比の確率密度関数を $(0 \sim 10 \mathrm{~m}) 、 \boldsymbol{\square}(10 \sim 20 \mathrm{~m}) 、 \Delta(20 \sim 50 \mathrm{~m}) 、 O(50 \sim 150 \mathrm{~m}) 、 \triangle(150 \mathrm{~m}$ 以上 $)$ で示して いる。

Fig. 7の水平最大加速度比、Fig. 8の上下最大加速度比を比べると、どちらす 2 点間距離が大きくなるほど 最大加速度比の確率密度関数が緩やかな形状を示すようになり、最大加速度比がより小さい值になる確率が 增加する傾向が見られる。

Fig. 9の南北成分の場合には 2 点間距離が増加するに従って、確率密度の形状は最大加速度比が 1 より小さ い值でピークをとるように変化しており、最大加速度比の最頻值の変化が明瞭に現れている。これに対して、 Fig.10の東西成分では 2 点間距離が増加しても最大加速度比の分布形があまり変化しておらず、最大加速度 の值が 2 点の位置によらずに、同じようにばらついているという結果が得られた。このことは、南北成分か ら得られた結果と相反するすのであり、今後、詳細な観測波形の検討が必要であると考えられる。

5.まとめ

ほぼ一様な地盤において、2 観測点間の距離が数十から数百メートルです、最大加速度は数割異なる。一 般にこの違いは 2 点間距離の増加にとあない顕著になっていく。また、 2 点間距離がわずか数メートルでも 最大加速度の観測值は1 2割程度ばらつく可能性がある。今後、最大加速度比が地盤構造や縟源に関するど のパラメータに影響を受けるのかを明確にする予定である。また、同様の検討を速度記録や変位記録につい ても行う予定である。

謝辞 本研究では、（財）票災予防協会、強震動アレー観測記録データベース（1992年10月、1993年12月） から東京大学生産技術研究所片山・山崎研究室、および、6 電力会社により提供されたデー夕を使用しまし た。

\section{参考文献}

（1）（財）磦災予防協会 推進委員会/作業部会「強縟動アレー観測記録データベース 解説資料集」19 92、1993. 


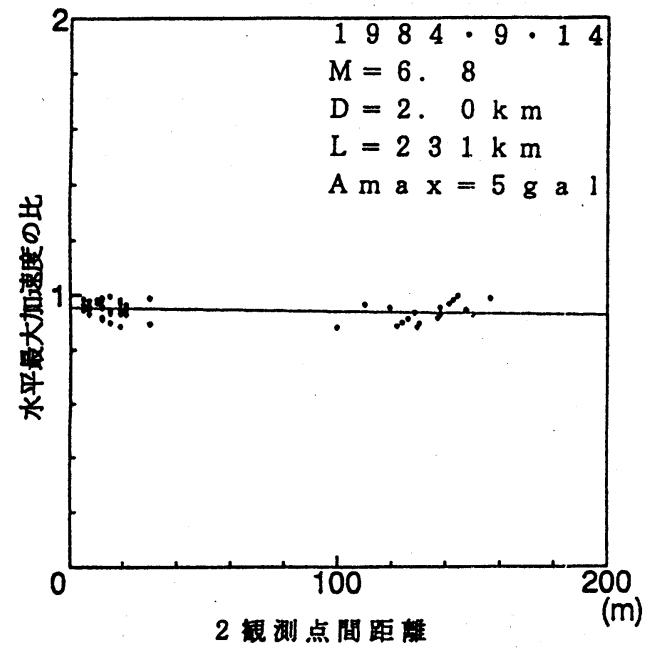

F 1 g.1.水平最大加速度のばらつきが少ない地䍚の列

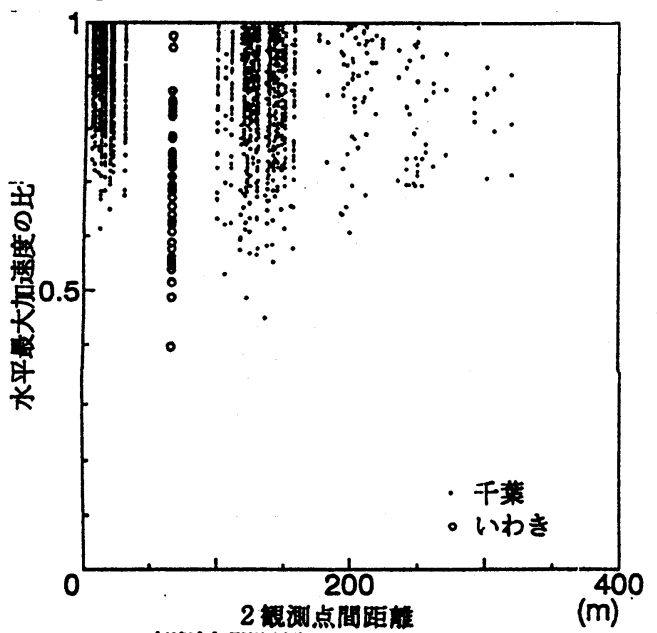

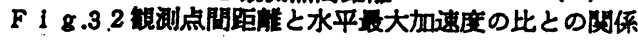

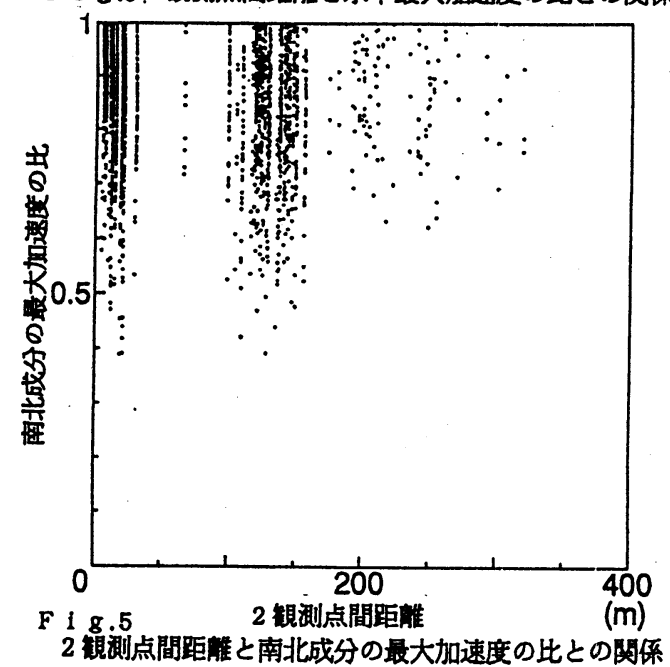

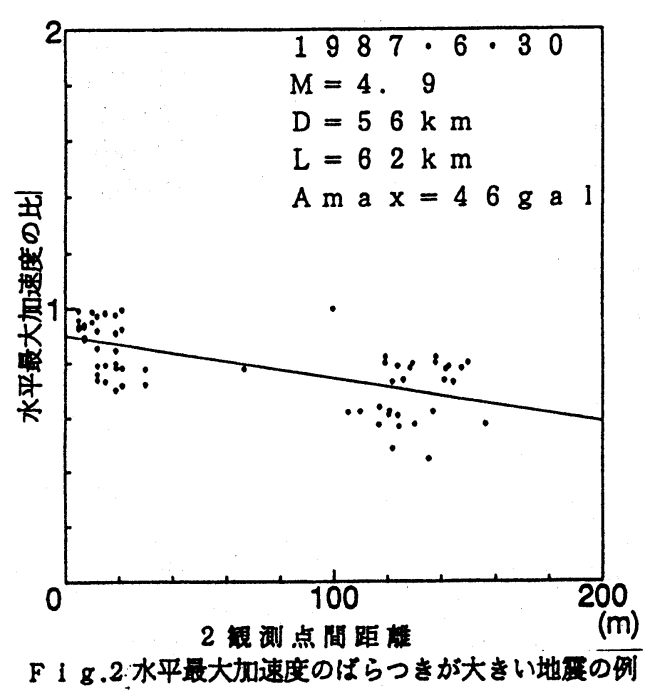

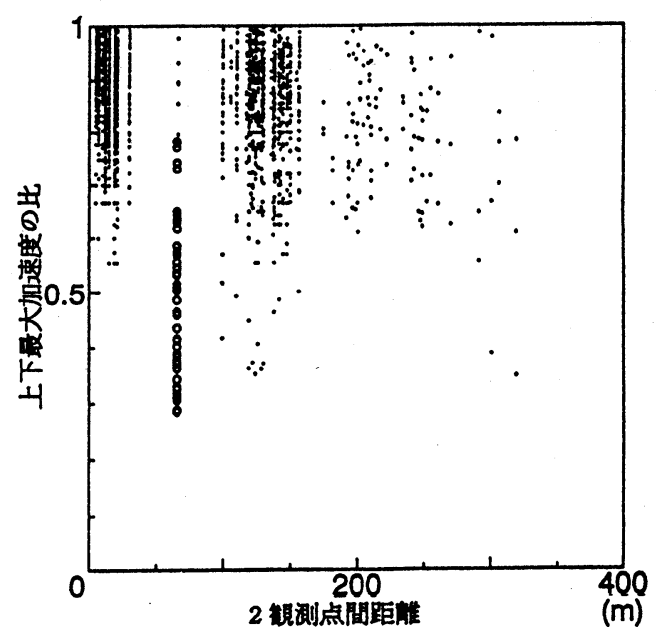

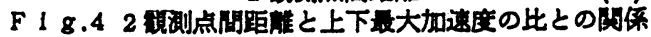

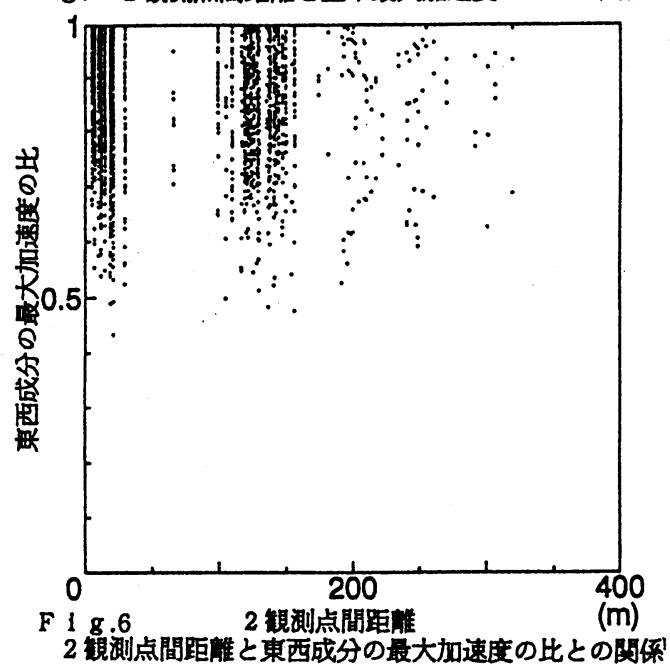




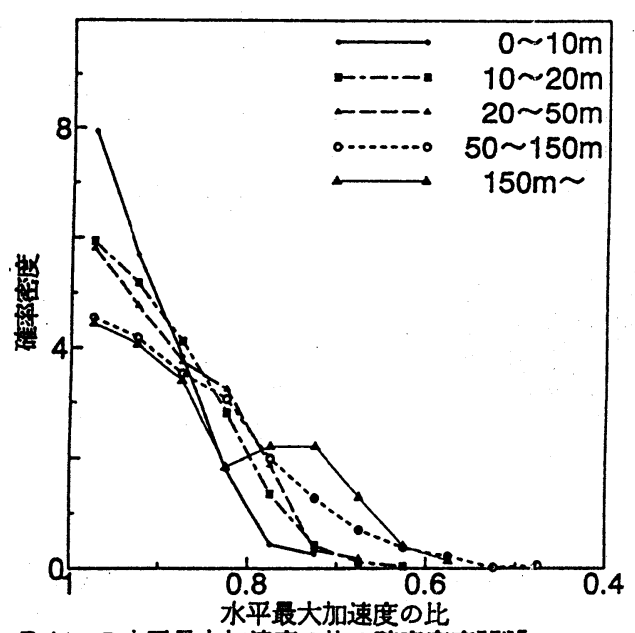

F 1 g .7. 水平最大加速度の比の確率密度関数

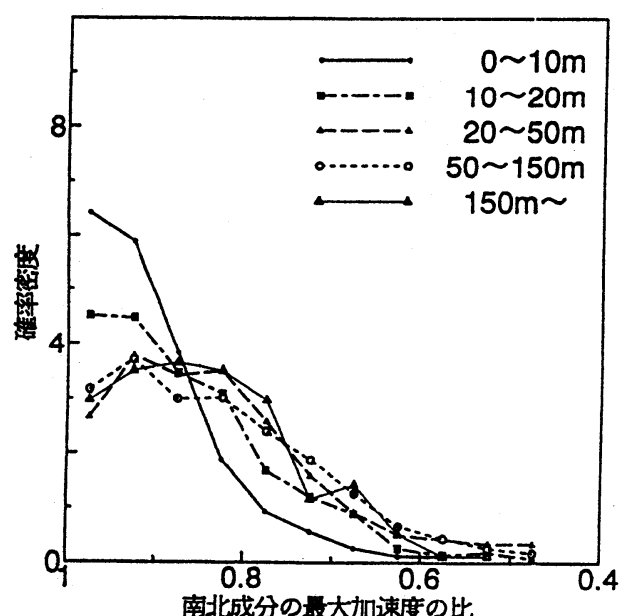

F 18.9 南北成分の最大加速度の比の確率密度跑数

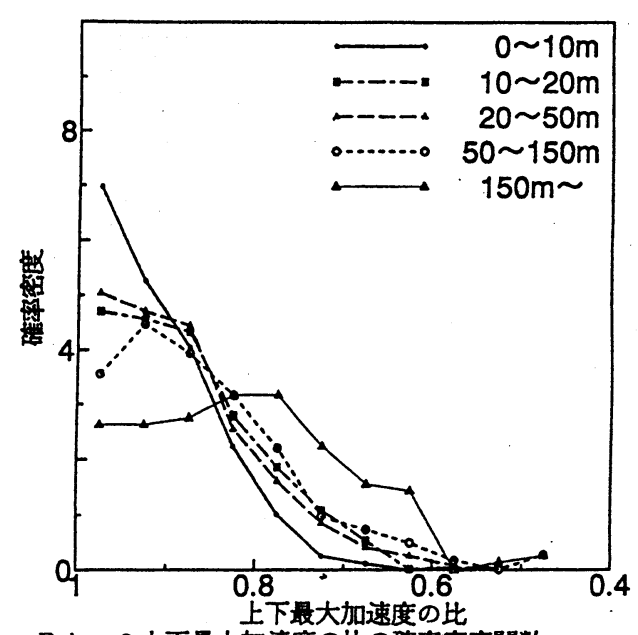

F 1 g .8 上下最大方速度の比の礁率密度関数

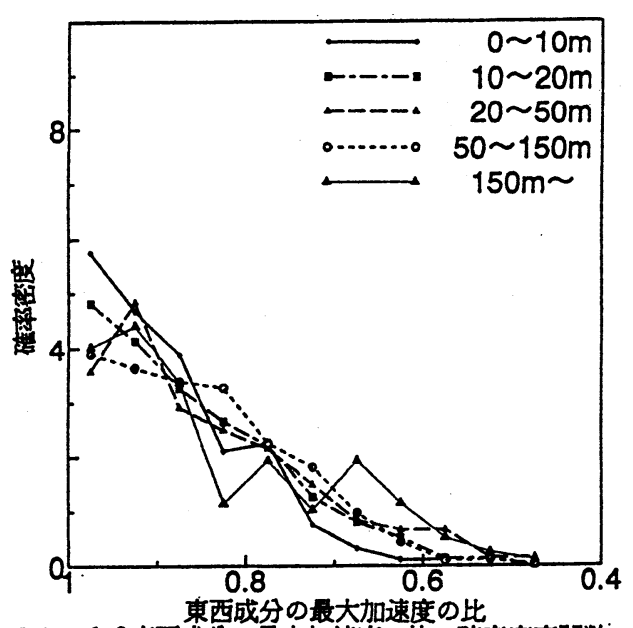

F 1 g .1 0東西成分の最大加速度の比の確率密度问数 